\title{
Nitrous oxide emissions from clover in the Mediterranean environment
}

\author{
Iride Volpi, ${ }^{1}$ Simona Bosco, ${ }^{1}$ Nicoletta Nassi o Di Nasso, ${ }^{1}$ Federico Triana, ${ }^{1}$ \\ Neri Roncucci, ${ }^{1}$ Patricia Laville, ${ }^{2}$ Simone Neri, ${ }^{3}$ Giorgio Virgili, ${ }^{3}$ Enrico Bonari ${ }^{1}$ \\ 'Institute of Life Sciences, Scuola Superiore Sant'Anna, Pisa, Italy; ${ }^{2}$ INRA UMR Environnement et \\ Grandes Cultures, Thiverval Grignon, France; ${ }^{3}$ West Systems s.r.l., Firenze, Italy
}

\begin{abstract}
Introducing nitrogen $\mathrm{N}_{2}$-fixing crops into cereal-based crop rotations reduces $\mathrm{N}$-fertiliser use and may mitigate soil emissions of nitrous oxide $\left(\mathrm{N}_{2} \mathrm{O}\right)$. However, the effect of the cultivation of $\mathrm{N}_{2}$-fixing crops on $\mathrm{N}_{2} \mathrm{O}$ emissions is still not well understood. $\mathrm{N}_{2} \mathrm{O}$ from $\mathrm{N}_{2}$-fixing crops can be emitted in two ways: during biological $\mathrm{N}_{2}$ fixation itself and when legume residues are returned to the soil. A field trial was carried out on clover (Trifolium squarrosum Savi) to test the role of leguminous crops on $\mathrm{N}_{2} \mathrm{O}$ emissions in the Mediterranean environment. Monitoring was performed from December 2013 to September 2014. Cumulated $\mathrm{N}-\mathrm{N}_{2} \mathrm{O}$ fluxes were calculated for the growing season (Phase 1) and the post-harvest period (Phase 2) in order to assess the importance of each phase. Our results did not show statistically significant differences between the two phases in term of contribution to the total cumulative $\mathrm{N}-\mathrm{N}_{2} \mathrm{O}$ emissions, in fact Phase 1 and Phase 2 accounted respectively for 43 and $57 \%$ of the total.
\end{abstract}

\section{Introduction}

Nitrous oxide $\left(\mathrm{N}_{2} \mathrm{O}\right)$ is an ozone depleting and long-lived (about 121

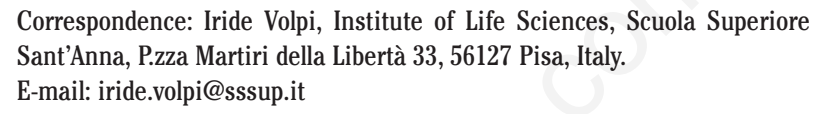

Key words: Clover; greenhouse gases monitoring; nitrous oxide; $\mathrm{N}_{2}$-fixing crops; mobile prototype.

Acknowledgements: this research was carried out with the contribution of the LIFE financial Instrument of the European Union, within the framework of the project LIFE+IPNOA Improved flux Prototypes for $\mathrm{N}_{2} \mathrm{O}$ emission from Agriculture (LIFE/11 ENV/T/302, www.ipnoa.eu).

Conflict of interest: the authors declare no potential conflict of interest.

Conference presentation: SIA XLIV Congress, Bologna, 2015.

Received for publication: 9 December 2015.

Revision received: 17 February 2016.

Accepted for publication: 22 February 2016.

(C) Copyright I. Volpi et al., 2016

Licensee PAGEPress, Italy

Italian Journal of Agronomy 2016; 11:728

doi:10.4081/ija.2016.728

This article is distributed under the terms of the Creative Commons Attribution Noncommercial License (by-nc 4.0) which permits any noncommercial use, distribution, and reproduction in any medium, provided the original author(s) and source are credited. years) greenhouse gas with a global warming potential about 298 times higher respect to $\mathrm{CO}_{2}$ (IPCC, 2013). Evaluating the magnitude of $\mathrm{N}_{2} \mathrm{O}$ emissions from agriculture and the possible mitigation strategies has a scientific and practical relevance, in fact emissions from agricultural and natural soils account for $56-70 \%$ of all the global sources (Syakila and Kroeze, 2011). $\mathrm{N}_{2} \mathrm{O}$ from soils is produced by microbial processes of nitrification and denitrification and its release is mainly related to nitrogen supply management (Rees et al., 2013; Snyder et al., 2014). The magnitude of $\mathrm{N}_{2} \mathrm{O}$ emissions is affected also by several site-specific aspects such as soil characteristics, climatic conditions and crop management (e.g., soil tillage, residue management, irrigation level etc.). The optimization of legumes management can offer an opportunity to reduce greenhouse gases (GHG) emissions from the agricultural sector (Smith et al., 2008). In fact, introducing $\mathrm{N}_{2}$-fixing legumes into cereal-based crop rotations reduces synthetic $\mathrm{N}$ fertilizer use and may mitigate direct $\mathrm{N}_{2} \mathrm{O}$ emissions from soil and reduces the use of fossil energy to produce $\mathrm{N}$ fertilizer (Jensen et al., 2012). $\mathrm{N}_{2} \mathrm{O}$ from legume crops can be produced both during nitrogen fixation and when crop residues decompose in the soil. The effect of the cultivation of legumes on $\mathrm{N}_{2} \mathrm{O}$ emissions is not well understood (Tellez-Rio et al., 2015). Recent studies observed a high variability between different sites and suggested that legume-derived $\mathrm{N}$ can be also a source of $\mathrm{N}_{2} \mathrm{O}$ emissions (Rochette and Janzen, 2005). There are weak evidences that the $\mathrm{N}$ fixation itself contributes significantly to the total emissions (Zhong et al., 2009; Jensen et al., 2012). Rochette et al. (2004) observed lower $\mathrm{N}_{2} \mathrm{O}$ emissions in legumes than in $\mathrm{N}$-fertilized crops. On the contrary, peaks of $\mathrm{N}_{2} \mathrm{O}$ emissions were recorded after clover harvest when residues decomposition occurred. Post-harvest peaks in $\mathrm{N}_{2} \mathrm{O}$ flux are mainly due to asynchrony between the $\mathrm{N}$ release and the demand of the following crop (Crews and Peolples, 2005). Legume residues decomposition is often fast as the carbon/nitrogen $(\mathrm{C} / \mathrm{N})$ ratio is low and the main sources of $\mathrm{N}_{2} \mathrm{O}$ from $\mathrm{N}_{2}$-fixing crops is the decomposition of the residues (Van Der Weerden et al., 1999; Baggs et al., 2000). Root nodules $\mathrm{C} / \mathrm{N}$ ratio is lower than the ratio of the other type of plants residues, thus in the soil decomposition of nodules is very fast and can be the major source of $\mathrm{N}_{2} \mathrm{O}$ during the postharvest period (Uchida and Akiyama, 2013). An experimental field was cultivated with clover (Trifolium squarrosum L.) with the aim to assess the magnitude of $\mathrm{N}_{2} \mathrm{O}$ daily flux and cumulative emissions in the Mediterranean environment. GHG monitoring and analysis of data were done both for the crop growth and the fallow period, in order to evaluate the contribution of the two phases to the overall cumulative emissions.

\section{Materials and methods}

\section{Site description and experimental set up}

The experimental field was located in the Centre for AgroEnvironmental Research E. Avanzi (CIRAA), in San Piero a Grado, in the Pisa (central Italy) coastal plain. Climate is Mediterranean with a mean annual precipitation of $907 \mathrm{~mm}$ and a mean annual temperature of $15^{\circ} \mathrm{C}$ (long term average 1986-2013). Clover (Trifolium squarrosum 
$L$.) was sown on Dec 2013 in a fertile sandy-loam soil. Tillage was conducted by ploughing $(30 \mathrm{~cm}$ depth) followed by rotary harrowing immediately before sowing. Weeds and pest control were never necessary during the trial. Harvest was performed at the end of May 2014. The experimental set up was constituted by four sampling areas $(5 \times 6 \mathrm{~m})$, each one provided with a polyvinyl chloride (PVC) collar for emissions monitoring. At harvest aboveground biomass was sampled in two areas of $0.5 \mathrm{~m}^{2}$ per plot and fresh weight was measured. Then, subsamples were dried at $60^{\circ} \mathrm{C}$ until constant weight to determine the dry biomass yield.

\section{Monitoring protocol and prototype characteristics}

The monitoring campaign started on 10 Dec 2013 and ended on 16 Sept 2014. Monitoring was carried out with a bimonthly frequency. Monitoring was performed from crop sowing to harvest (Phase 1) and during 4 months of the fallow period (Phase 2). Due to unfavourable environmental condition cultural operations were delayed and it was not possible to maintain the field trial until the tillage for the following crop, so this study does not include $\mathrm{N}_{2} \mathrm{O}$ monitoring after the incorporation of crop residues with tillage.

$\mathrm{N}_{2} \mathrm{O}$ was monitored directly in the field with the LIFE+IPNOA mobile prototype described by Bosco et al. (2015) through the non-steady state chamber technique. GHG concentration within the chamber was measured at a time step of 1 second ( $\mathrm{ppb} \mathrm{s}^{-1}$ ), the increase in the headspace was checked for linearity over a period of 2-3 min. Data were recorded by a palm top computer connected via Bluetooth ${ }^{\circledR}$. Each PVC collar had a $15 \mathrm{~cm}$ radius, was $15 \mathrm{~cm}$ high and was inserted for $5 \mathrm{~cm}$ into the soil.

In order to follow crop growth three PVC stackable extensions were installed on the collars when needed. Soil temperature and volumetric water content were recorded beside each collar at a depth of $5 \mathrm{~cm}$ by a dielectric probe (Decagon Devices GS3; Decagon Devices, Inc., Pullman, WA, USA) linked to the prototype via Bluetooth ${ }^{\circledR}$. Water filled pore space (\%) (WFPS) was calculated from total porosity using bulk density considering the particle density as $2.65 \mathrm{~g} \mathrm{~cm}^{-3}$.

\section{Mineral nitrogen determination in soil}

Soil samples for mineral nitrogen determination were collected once a month in the $0-20 \mathrm{~cm}$ layer during a monitoring day. A sample from each sampling area was composed of three soil cores. Samples were frozen at $-20^{\circ} \mathrm{C}$. A $12 \mathrm{~g}$ subsample of moist soil was extracted with $1 \mathrm{M}$ $\mathrm{KCl}$ using a 1:10 soil: extractant ratio and 30 min shaking time. Concentrations of $\mathrm{N}-\mathrm{NO}_{3}$ were determined with ultraviolet spectrophotometric technique (Goldman and Jacobs, 1961). $\mathrm{N}-\mathrm{NH}_{4}$ concentrations were determined photometrically after using the Spectroquant® kit (Merck Millipore Corp., Billerica, MA, USA). Soil mineral N content was calculated from $\mathrm{N}$ sample concentration considering soil dry weight.

\section{Statistical analysis}

Statistical analysis was performed with the R software (R Core Team 2015; R Foundation for Statistical Computing, Vienna, Austria). Level of significance was $\alpha=0.05$. Nitrous oxide flux was calculated by linear regression of $\mathrm{N}_{2} \mathrm{O}$ concentration increase during chamber closure time taking into account air temperature, atmospheric pressure and headspace volume. Cumulative $\mathrm{N}_{2} \mathrm{O}$ emissions over the period were calculated by linear interpolation of two following sampling dates and the numerical integration over time. Differences between Phase 1 and Phase 2 for cumulative $\mathrm{N}_{2} \mathrm{O}$ emissions were tested with a one-way analysis of variance (ANOVA). Relationships between $\mathrm{N}_{2} \mathrm{O}$ daily flux and soil characteristics were tested after log transformation by stepwise multiple linear regression analysis.

\section{Results}

\section{Meteorological pattern, nitrous oxide fluxes, soil water filled pore space and temperature, soil $\mathrm{NO}_{3}{ }^{-}$ and $\mathrm{NH}_{4}{ }^{+}$}

In winter 2014, heavy rains occurred from January to March $(>500$ $\mathrm{mm}$ ) causing a data gap from 9 Jan 2014 to 10 Mar 2014 in the $\mathrm{N}_{2} \mathrm{O}$ flux measurements (Figure 1A).

During the whole monitoring period the total rainfall was $1033 \mathrm{~mm}$, $12 \%$ highest than the long-term yearly average. The highest recorded mean daily temperature was $36.0^{\circ} \mathrm{C}$ on 9 Jun 2014 , while the minimum daily temperature was $-1^{\circ} \mathrm{C}$ on $17 \mathrm{Dec} 2013$. The average daily temperature along the monitoring period was $15.5^{\circ} \mathrm{C}$. The dry yield at harvest was about $10 \mathrm{Mg} \mathrm{ha}^{-1}$.

The highest $\mathrm{N}_{2} \mathrm{O}$ daily flux was $0.67 \pm 0.04 \mathrm{mg} \mathrm{N}_{2} 0 \mathrm{~m}^{-2}$ day ${ }^{-1}$ on 10 Dec 2013, the lowest was $-0.11 \pm 0.07 \mathrm{mg} \mathrm{N}_{2} \mathrm{O} \mathrm{m}^{-2}$ day $^{-1}$ on $10 \mathrm{Mar} 2014$ and the mean was $0.32 \pm 0.06 \mathrm{mg} \mathrm{N}_{2} \mathrm{O} \mathrm{m}^{-2}$ day $^{-1}$ (Figure 1B).

$\mathrm{N}_{2} \mathrm{O}$ flux decreased from December until the end of March, afterwards the magnitude of the flux increased and reached a peak in April 22 with $0.61 \pm 0.12 \mathrm{mg} \mathrm{N}_{2} \mathrm{O} \mathrm{m}^{-2}$ day $^{-1}$. The mean $\mathrm{N}_{2} \mathrm{O}$ flux during Phase 1 was $0.29 \pm 0.03 \mathrm{mg} \mathrm{N}_{2} \mathrm{O} \mathrm{m}^{-2}$ day $^{-1}$. In Phase 2 the $\mathrm{N}_{2} \mathrm{O}$ flux magnitude was stable around the average of $0.37 \pm 0.02 \mathrm{mg} \mathrm{N}_{2} \mathrm{O} \mathrm{m} \mathrm{m}^{-2}$ day ${ }^{-1}$. Statistical analysis did not show differences between the mean daily fluxes of the two phases. Daily mean, minimum and maximum values of N-NO${ }_{3}$ and $\mathrm{N}-\mathrm{NH}_{4}$ soil concentration, soil WFPS and temperature during Phase 1 and 2 were reported in Table 1.

Peaks in $\mathrm{N}^{-\mathrm{NO}_{3}}$ concentration (19.2 ppm) on $22 \mathrm{Apr} 2014$ and 24 July 2014 (15.3 ppm) (Figure 1C) corresponded to peaks in $\mathrm{N}_{2} \mathrm{O}$ flux. Relationship between the log transformed $\mathrm{N}_{2} \mathrm{O}, \mathrm{N}-\mathrm{NO}_{3}$ and $\mathrm{N}-\mathrm{NH}_{4}$ soil concentration and soil temperature during Phase 1 was described by a multiple linear regression $\left(\mathrm{P}<0.01\right.$, adjusted $\left.\mathrm{r}^{2}=0.4\right)$.

\section{Cumulative $\mathrm{N}$ - Nitrous oxide emissions}

Total cumulative emissions over the monitoring period (280 days)

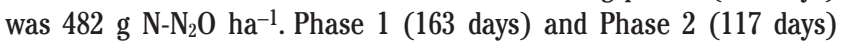
accounted respectively for 43 and $57 \%$ of the total. Cumulative $\mathrm{N}-\mathrm{N}_{2} \mathrm{O}$ emissions in the two phases did not show significant differences.

Table 1. Mean, minimum and maximum values of $\mathrm{N}-\mathrm{NO}_{3}$ and $\mathrm{N}-\mathrm{NH}_{4}$ concentration in soil, soil water filled pore space and temperature during Phase 1 and 2 . Soil water filled pore space and soil temperature were recorded at $5 \mathrm{~cm}$ depth. With Phase 1 is identified the growing period, while Phase 2 is the period after the crop harvest.

\begin{tabular}{|c|c|c|c|c|c|c|c|c|c|c|c|c|}
\hline \multirow[t]{2}{*}{ Phase } & \multicolumn{3}{|c|}{$\mathrm{N}-\mathrm{NO}_{3}(\mathrm{ppm})$} & \multicolumn{3}{|c|}{$\mathrm{N}-\mathrm{NH}_{4}(\mathrm{ppm})$} & \multicolumn{3}{|c|}{ WFPS (\%) } & \multicolumn{3}{|c|}{ Soil temperature $\left({ }^{\circ} \mathrm{C}\right)$} \\
\hline & Mean & Min & Max & Mean & Min & $\operatorname{Max}$ & Mean & Min & $\operatorname{Max}$ & Mean & Min & Max \\
\hline 1 & 8.6 & 0.0 & 19.2 & 2.8 & 1.5 & 3.7 & 29.7 & 9.1 & 62.3 & 17.2 & 10.0 & 24.8 \\
\hline 2 & 9.1 & 3.8 & 15.3 & 3.8 & 2.5 & 6.2 & 29.1 & 5.7 & 63.5 & 32.7 & 29.9 & 35.5 \\
\hline
\end{tabular}

WFPS, water filled pore space. 

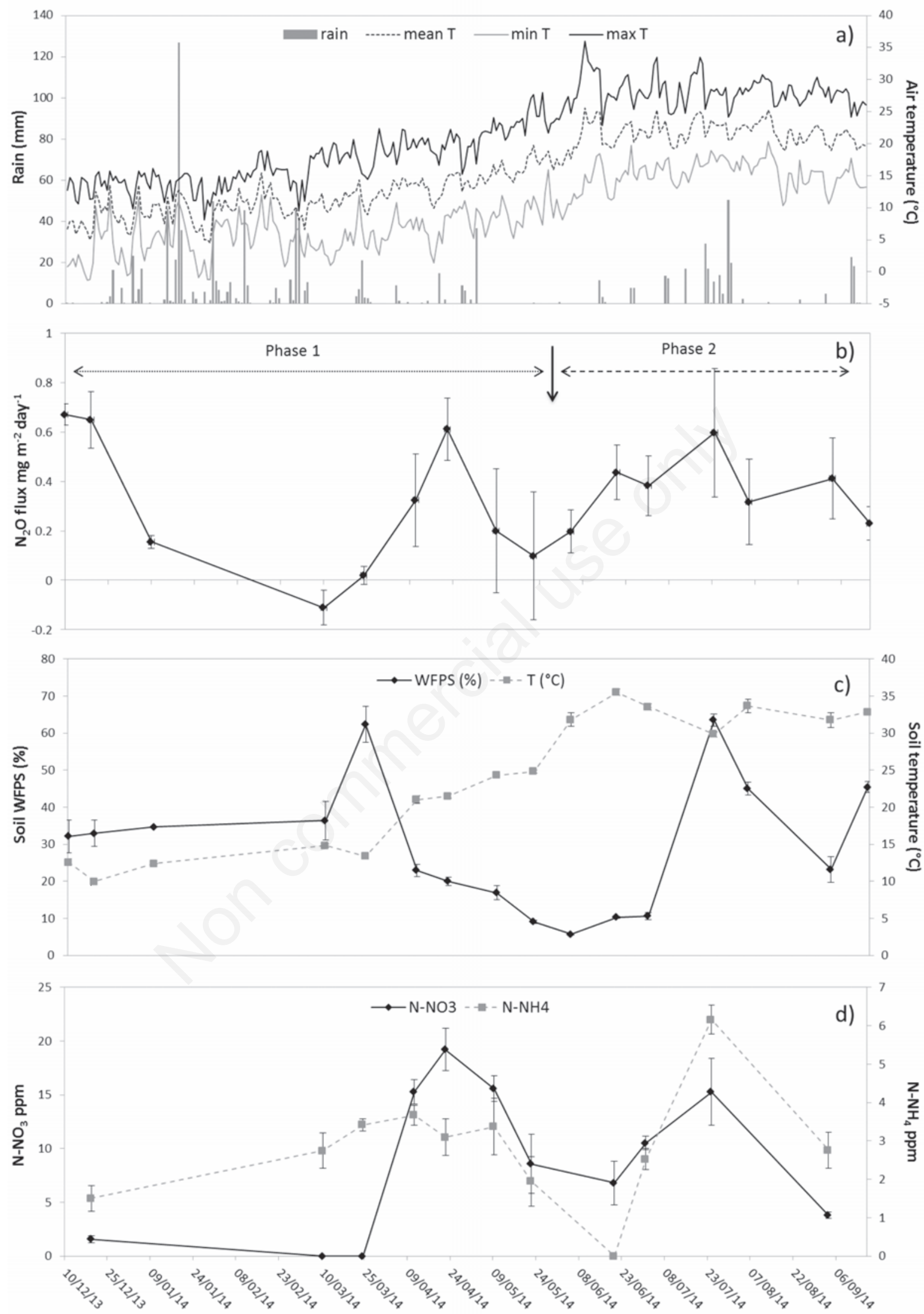

Figure 1. Pattern of meteorological data (A), daily soil $\mathrm{N}_{2} \mathrm{O}$ flux $(\mathrm{B})$, soil water filled pore space (WFPS) and temperature $(\mathrm{C})$, $\mathrm{N}_{-} \mathrm{NO}_{3}$ and $\mathrm{N}-\mathrm{NH}_{4}(\mathrm{D})$ soil concentration during the monitoring campaign. 


\section{Discussion}

Mean daily $\mathrm{N}_{2} \mathrm{O}$ flux in Phase 2 showed a very limited range of variation, while during the presence of the crop (Phase 1) peaks were detectable in few dates, at the beginning of the monitoring campaign and in April. The high $\mathrm{N}_{2} \mathrm{O}$ flux at the sowing was possibly due to the incorporation of the previous crop residues with tillage (Baggs et al., 2000). From January to the beginning of April $\mathrm{N}_{2} \mathrm{O}$ flux was low, concurrently with a very low $\mathrm{N}^{-\mathrm{NO}_{3}}$ concentration in soil (around $0 \mathrm{ppm}$ ). From April to the beginning of May high $\mathrm{N}_{2} \mathrm{O}$ fluxes corresponded to a high $\mathrm{N}-\mathrm{NO}_{3}$ availability, probably promoted by the $\mathrm{N}$-fixation activity of the plants. This can be explained by the significant multiple linear regression found for Phase 1 between $\mathrm{N}_{2} \mathrm{O}, \mathrm{N}-\mathrm{NO}_{3}, \mathrm{~N}_{-} \mathrm{NH}_{4}$ and soil temperature, where the $\mathrm{N}-\mathrm{NO}_{3}$ is the variable with the highest predictive capability $(\mathrm{P}<0.001)$. During Phase 2 the $\mathrm{N}_{2} \mathrm{O}$ flux magnitude was stable, likely due to the constant degradation rate of the roots nodules (Uchida and Akiyama, 2013). Cumulative $\mathrm{N}-\mathrm{N}_{2} \mathrm{O}$ emissions reported by Barton et al. (2011) from a semiarid climate were more than three times lower that our value ( $127 \mathrm{~g} \mathrm{~N}-\mathrm{N}_{2} \mathrm{O}$ ha $^{-1}$ for 350 days). Our cumulative emissions were slightly lower than mean data from papers on Mediterranean environment reported in the review of Aguilera et al. (2013) on annual basis $\left(700 \mathrm{~g} \mathrm{~N}-\mathrm{N}_{2} 0 \mathrm{ha}^{-1} \mathrm{y}^{-1}\right)$. Flessa et al. (2002) in a temperate climate reported cumulative $\mathrm{N}-\mathrm{N}_{2} \mathrm{O}$ higher than our value, around $2 \mathrm{~kg} \mathrm{~N}-\mathrm{N}_{2} \mathrm{O} \mathrm{ha}^{-1} \mathrm{y}^{-1}$ from lupine. The same author observed that cumulative emissions from lupine were lower than emissions from fertilized crops in the same area but highlighted that the ploughing of a clover field after the harvest had a negative effect on the growing period of the subsequent crop enhancing emissions (7-12 kg N-N $20 \mathrm{ha}^{-1} \mathrm{y}^{-1}$ ), probably due to the mineralization of biologically $\mathrm{N}$ fixed residue and the increased microbial respiration. Our results confirmed that $\mathrm{N}-\mathrm{N}_{2} \mathrm{O}$ cumulative emissions from clover in both during crop growth and in fallow period were smaller compared with the cumulative $\mathrm{N}-\mathrm{N}_{2} \mathrm{O}$ of a fertilized durum wheat (1831 $\mathrm{g} \mathrm{N}^{-} \mathrm{N}_{2} \mathrm{O}$ ha ${ }^{-1}$ ) cultivated at the same study site in the 2013-2014 growing season (Bosco et al., 2015).

\section{Conclusions}

Our results highlighted that $\mathrm{N}-\mathrm{N}_{2} \mathrm{O}$ emissions from clover, both during the crop growth and in fallow period, were lower than emissions from a fertilized crop in the same environment. Between the two periods no significant differences were found, so the two phases contribute equally to the total cumulative $\mathrm{N}-\mathrm{N}_{2} \mathrm{O}$ emissions. Anyway our study did not include $\mathrm{N}_{2} \mathrm{O}$ flux monitoring after incorporation of clover residues with tillage, which seems to represent a high source of $\mathrm{N}_{2} \mathrm{O}$ emissions.

\section{References}

Aguilera E, Lassaletta L, Gattinger A, Gimeno BS, 2013. Managing soil carbon for climate change mitigation and adaptation in Mediterranean cropping systems: a meta-analysis. Agric. Ecosyst. Environ. 168:25-36.

Baggs EM, Rees RM, Smith KA, Vinten AJA, 2000. Nitrous oxide emission from soils after incorporating crop residues. Soil Use Manage. 16:82-7.

Barton L, Butterbach-Bahl K, Kiese R, Murphy DV, 2011. Nitrous oxide fluxes from a grain-legume crop (narrow-leafed lupin) grown in a semiarid climate. Glob. Chang. Biol. 17:1153-66.

Bosco S, Volpi I, Nassi o Di Nasso N, Triana F, Roncucci N, Tozzini C,
Villani R, Laville P, Neri S, Mattei F, Virgili G, Nuvoli S, Fabbrini L, Bonari E, 2015. LIFE+IPNOA mobile prototype for the monitoring of soil $\mathrm{N}_{2} \mathrm{O}$ emissions from arable crops: first-year results on durum wheat. Ital. J. Agron. 10:124-31.

Crews TE, Peoples MB, 2005. Can the synchrony of nitrogen supply and crop demand be improved in legume and fertilizer-based agroecosystems? Nutr. Cycl. Agroecosystems 72:101-20.

Flessa H, Ruser R, Schilling R, Loftfield N, Munch JC, Kaiser EA, Beese F, 2002. N2O and CH4 fluxes in potato fields: automated measurement, management effects and temporal variation. Geoderma 105:307-25.

Goldman E, Jacobs R, 1961. Determination of nitrates by ultraviolet absorption. J. Am. Water Works Assoc. 53:187-91.

IPCC (Intergovernmental Panel on Climate Change), 2013. Climate Change 2013: the physical science basis. In: Stocker TF, Qin D, Plattner G-K, Tignor M, Allen SK, Boschung J, Nauels A, Xia Y, Bex V, Midgley PM (Eds.), Contribution of working group I to the fifth assessment report of the intergovernmental panel on climate change. Cambridge University Press, Cambridge, United Kingdom and New York, NY, USA, p 1535.

Jensen ES, Peoples MB, Boddey RM, Gresshoff PM, Henrik HN, Alves BJR, Morrison MJ, 2012. Legumes for mitigation of climate change and the provision of feedstock for biofuels and biorefineries. Agron. Sustain. Dev. 32:329-64.

Rees RM, Augustin J, Alberti G, Ball BC, Boeckx P, Cantarel A, Castaldi S, Chirinda N, Chojnicki B, Giebels M, Gordon H, Grosz B, Horvath L, Juszczak R, Kasimir Klemedtsson $\AA$, Klemedtsson L, Medinets S, Machon A, Mapanda F, Nyamangara J, Olesen JE, Reay DS, Sanchez L, Sanz Cobena A, Smith KA, Sowerby A, Sommer M, Soussana JF, Stenberg M, E. Topp CF, van Cleemput 0, Vallejo A, Watson CA, Wuta M, 2013. Nitrous oxide emissions from European agriculture - an analysis of variability and drivers of emissions from field experiments. Biogeosciences 10:2671-82.

Rochette P, Angers DA, Bélanger G, Chantigny MH, Prévost D, Lévesque G, 2004. Emissions of $\mathrm{N}_{2} \mathrm{O}$ from alfalfa and soybean crops in Eastern Canada. Soil Sci. Soc. Am. J. 68:493-506.

Rochette P, Janzen HH, 2005. Towards a revised coefficient for estimating $\mathrm{N}_{2} \mathrm{O}$ emissions from legumes. Nutr. Cycl. Agroecosyst. 73:171-9.

Smith P, Martino D, Cai Z, Gwary D, Janzen H, Kumar P, McCarl B, Ogle S, O'Mara F, Rice C, Scholes B, Sirotenko 0, Howden M, McAllister T, Pan G, Romanenkov V, Schneider U, Towprayoon S, Wattenbach M, Smith J, 2008. Greenhouse gas mitigation in agriculture. Philos. Trans. R. Soc. Lond. B. Biol. Sci. 363:789-813.

Snyder CS, Davidson EA, Smith P, Venterea RT, 2014. Agriculture: sustainable crop and animal production to help mitigate nitrous oxide emissions. Curr. Opin. Environ. Sustain. 9-10:46-54.

Syakila A, Kroeze C, 2011. The global nitrogen budget revisited. Greenhouse Gas Meas. Manage. 1:17-26.

Tellez-Rio A, García-Marco S, Navas M, López-Solanilla E, Luis Tenorio J, Vallejo A, 2015. N2O and CH4 emissions from a fallow-wheat rotation with low $\mathrm{N}$ input in conservation and conventional tillage under a Mediterranean agroecosystem. Sci. Total Environ. 508:85-94.

Uchida Y, Akiyama H, 2013. Mitigation of postharvest nitrous oxide emissions from soybean ecosystems: a review. Soil Sci. Plant Nutr. 59:477-87.

Van Der Weerden TJ, Sherlock RR, Williams PH, Cameron KC, 1999. Nitrous oxide emissions and methane oxidation by soil following cultivation of two different leguminous pastures. Biol. Fertil. Soils. 30:52-60.

Zhong Z, Lemke RL, Nelson LM, 2009. Nitrous oxide emissions associated with nitrogen fixation by grain legumes. Soil Biol. Biochem. 41:2283-91. 